\title{
The Effect of Transformational Leadership, PEP, POS and Organizational Commitment on OCB: A Literature Review
}

\author{
Betsy Hariani ${ }^{1}$, Erni Masdupi ${ }^{2}$ \\ ${ }^{1}$ Universitas Negeri Padang, Padang, Indonesia, $ه$ hrbetsy@gmail.com \\ 2Universitas Negeri Padang, Padang, Indonesia, \emasdupi@yahoo.com
}

\begin{abstract}
This paper is a literature study to analyze Effect of Transformational Leadership, PEP and POS on OCB. This type of research is explanatory research, looking at the relationship among free variables human capital, motivation, and job satisfaction on employee performance. The purpose of this study is to collect and analyze the published articles regarding Effect of Transformational Leadership, PEP and POS on OCB. The research design is a literature review. The articles have been published in the last five years representing of six different academically. The results of the review literature find out that Transformational Leadership, PEP and POS on OCB. The results of this review are only a conceptual starting point for starting an integrated discipline.
\end{abstract}

Keywords: transformational leadership, PEP and POS, OCB, organizational commitment

\section{Introduction}

To foster organizational behavior of citizenship behavior, many stimulants are needed, including being influenced by leaders who can provide conducive situations and enthusiasm in completing work assignments, pride in being able to work in organizations that are considered prestige and support from the organization for developing and fulfilling workers' needs, resulting in increased commitment to the organization. Organizational Citizenship Behavior behavior is a form of employee contribution that exceeds official work descriptions and is done voluntarily, even though formally it is not recognized by reward by the organization, but the contribution given by the employee can improve organizational functions more effectively and efficiently. Transformational leadership style is one that can influence organizational citizenship behavior of employees. Leaders can develop organizational citizenship behavior in employees. The mechanism of organizational citizenship behavior taught by leaders is then adapted by their followers through the process of socialization. Through organizational citizenship behavior, employees need the right leadership, so that it can improve the behavior of a strong organizational citizenship

Furthermore, perceived external prestige or perceived external prestige can also influence organizational citizenship behavior of employees. The benefits of the perception of external prestige are positive for individual employees so that they are more enthusiastic in carrying out their work because they feel like they have a good reputation for having a good reputation. . That pride is a sense of belonging to the company. Perceived organizational support or perceptions of organizational support influences the organizational organizational citizenship behavior of employees. Providing organizational support to employees tends to generate feelings of responsibility towards the organization, strengthen the bond between employers and employees, and then increase the feeling of the obligation of employees to contribute more to the organization. Referring to reciprocity norms, there is a view that employees feel that the implementation of support is perceived as being carried out by their company, making employees feel valued and in return will do the best for their company where they work, such as increasing OCB in behavior-drivers and extra-roles. Organizational goals and perceived performance, can parties can foster a sense of emotional attachment, identification and the involvement of an employee in an organization (affective commitment), discouraging the intention to leave the company feeling continuance commitment and psychologically bound to an 
organization-based employee of an on feelings such as loyalty, affection, warmth, ownership, pride, happiness (normative commitment). That is, organizational commitment and growth for organizational citizenship behavior and work performance of employees.

Based on the theories described earlier, the conceptual framework in this study can be explained in the picture as follows:

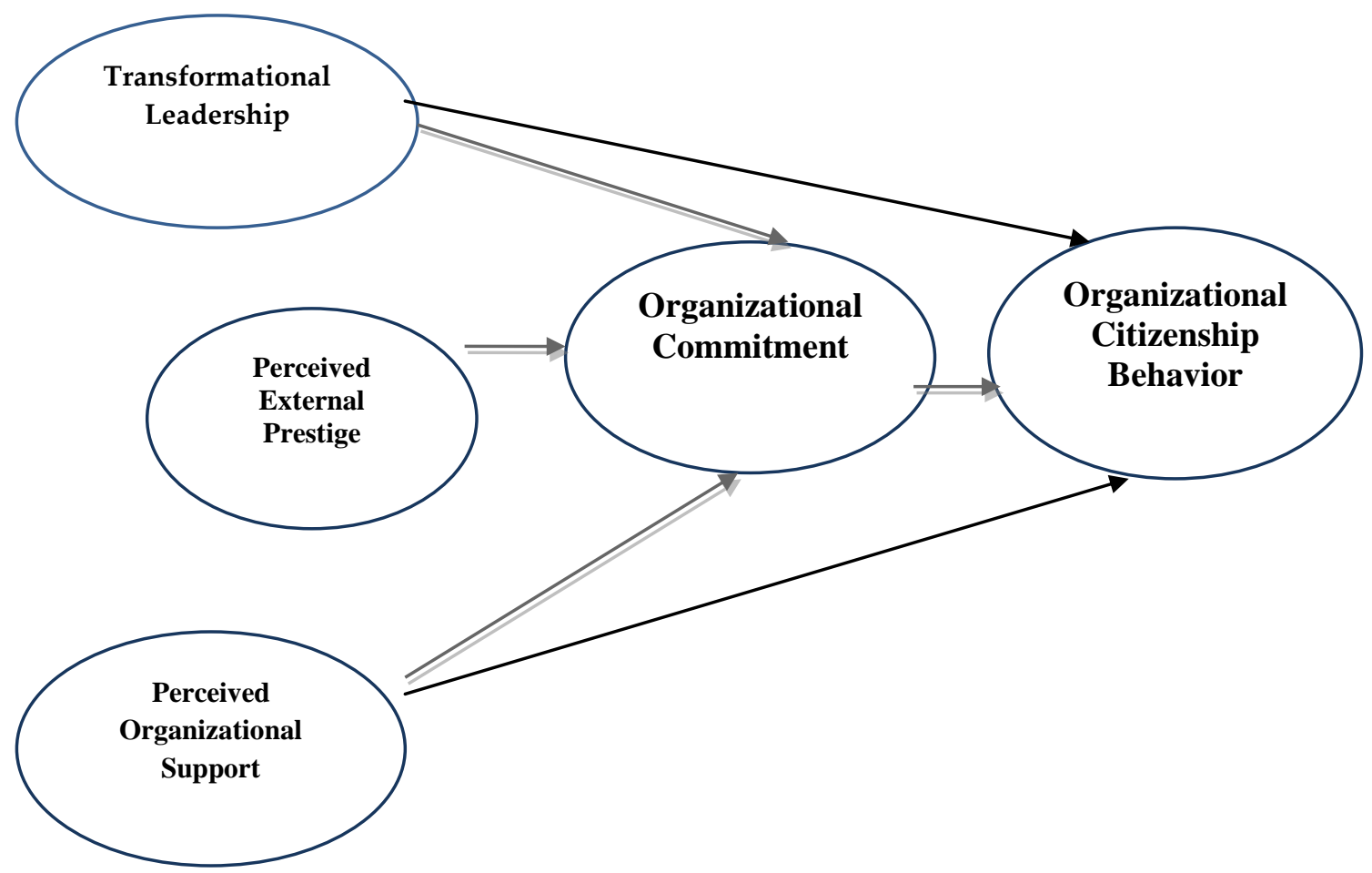

Figure 1 Conceptual Framework

\section{Methods}

The method used in this study literature adopts Systematic Literature Review (SRL) proposed by Xiao \& Watson (2019). SLR is defined as a way of identifying, evaluating and interpreting all available research that is relevant to research questions or domain topics or phenomena that are of interest to researcher. Xiao \& Watson (2019) divided the guidelines for implementing SLR into 3 phases, namely: (1) planning; (2) execution; and (3) analysis of results.

In this literature review, the data sources that will be used are papers available on the website page: (1) Emerald Insight; (2) Wiley InterScience; and (3) Science Direct. The strategy in conducting a search is built through the determination of keywords and synonyms from the focus of the study. Keywords and synonyms are connected to the logical OR and OR connectors.

The paper selection procedure was carried out with the speed reading technique of all primary study candidates. Fast reading is reading the abstraction section of the available paper. Furthermore, based on the inclusion and exclusion criteria made, it can be determined whether the paper can be used as a primary study. Based on the planned review, the next step is to execute the plan. Execute search strings on web pages that are used as sources.

Based on the search results on the website page which made the data source produced as many as 1,864 articles which were primary study candidates, then made one, then screened whether the title in the article was the same or not. After screening, 98 articles were the same as the title. Of the 98 articles then screened based on eligibility according to the inclusion and exclusion criteria obtained 27 articles for further review. 


\section{The Effect of Transformational Leadership on Organizational Commitment.}

Transformational leadership can be said as an effective leadership style in determining employee organizational commitment. If a leader has the ability to empower, move and motivate employees, this can affect organizational commitment. If a leader is able to understand the needs of subordinates, is able to motivate his subordinates, be able to provide solutions and solve problems and also be able to act as a mentor in educating subordinates to achieve achievements, it results in growing employee organizational commitment, but if leaders are less responsive in matters previously mentioned, this will have an impact on reducing employee organizational commitment. According to the Health Minister in his research entitled "Transformational leadership and organizational commitment: Mediating the role of leader-member exchange", adopting the perspective of social exchange theory to examine the relationship between transformational leadership and organizational commitment, concluded that affective commitment is one indicator of organizational commitment. has a broader impact on employee retention, job satisfaction and greater pro-social behavior. A supportive transformational leadership style fosters an emotional bond between leaders and followers, thereby reducing the desire to leave the organization. While the personal appreciation of transformational leadership will foster loyalty for followers and increase ongoing commitment (Keskes et al., 2018). Organizational commitment can be measured through affective commitment, ongoing commitment, and normative commitment. Organizational commitment will increase if a leader can foster a sense of trust and values towards the organization.

\section{The Effects of Perceived External Prestige on Organizational Commitment}

Perceived externla prestige or PEP is the perception of the organization's external identity regarding the image of the organization, namely symbols and interpretations that are evaluated externally about the company by parties from outside the organization. The image of the organization becomes important for many companies because sometimes their performance and the smooth running of company activities can also depend on reputation. The company's reputation is also important for the company's stakeholders. The image of the organization also has an influence, although indirect, on employees, because they accept and interpret various messages from external parties and form opinions about how outsiders perceive the company. The PEP phenomenon is also specifically to assess employee beliefs about how outsiders assess the status and image of their organization. The benefit of having PEP for employees is to foster a positive evaluation of themselves for individual employees so that they will be hesitant to leave the current organization for other organizations if they are considered less prestigious. This value in turn has an impact on employees as members of the organization resulting in more commitment to the organization. According to DaeSeok Kang (Jim \& Hayeon, 2011) in his research entitled "The effects of perceived external prestige, ethical climate organization, and leader-member exchange (LMX) quality on employees' commitments and their subsequent attitudes" concluded that Perceived externa prestige is positively related to the organizational commitment of the research sample, which is 477 employees who work at fifteen of the leading companies in South Korea, so that with positive perceptions of the external picture of their organization they fail to stop and ultimately foster a strong organizational commitment to themselves employee.

\section{The Effects of Perceived Organizational Support on Organizational Commitment.}

Perceived Organizational Support is defined as the general beliefs of employees about how organizations value employee contributions and care about employee welfare. Organizational commitment is a form of bonding and loyalty attitudes that employees have to actively involve themselves in the organization for organizational progress (Kartika et al., 2014). However, not all organizations provide full support to employees, therefore the solution arises, one of which is by increasing the work capacity of employees to minimize the emergence of perceived low organizational support from employees, which impacts on the desire of employees to leave the organization (Yahya et al., 2012 ). Providing organizational support to employees tends to generate 
feelings of responsibility towards the organization, strengthen ties between superiors and employees, and then increase the sense of obligation of employees to contribute more to the organization (Newman et al., 2015). Perceived high organizational support can make employees feel they have an obligation to contribute more and care about the welfare of the organization and help the organization in achieving its goals so that it can ultimately increase commitment to the organization. The results of the study from Perreira (Perreira \& Berta, 2015) under the title Increasing OCB: the influence of commitment and organizational support and justice found that in the interests of increasing the behavior of OCB extra-role workplaces related to work attitudes and work motivation, one of which arose from the feeling of support from the organization to employees that shows the influence of organizational justice so that it increases affective commitment to the formation of behavioral intentions on employees. Organizational support that gives a positive influence on increasing commitment to the organization also gives employees a positive influence on extra role behavior in the work environment. The perception variables of organizational support have a positive and significant influence on organizational commitment.

\section{The Effects of Perceived Organizational Support on Organizational Commitment.}

Perceived Organizational Support is defined as the general beliefs of employees about how organizations value employee contributions and care about employee welfare. Organizational commitment is a form of bonding and loyalty attitudes that employees have to actively involve themselves in the organization for organizational progress (Kartika et al., 2014). However, not all organizations provide full support to employees, therefore the solution arises, one of which is by increasing the work capacity of employees to minimize the emergence of perceived low organizational support from employees, which impacts on the desire of employees to leave the organization (Yahya et al., 2012 ). Providing organizational support to employees tends to generate feelings of responsibility towards the organization, strengthen ties between superiors and employees, and then increase the sense of obligation of employees to contribute more to the organization (Newman et al., 2015). Perceived high organizational support can make employees feel they have an obligation to contribute more and care about the welfare of the organization and help the organization in achieving its goals so that it can ultimately increase commitment to the organization. ,The results of the study from Perreira (Perreira \& Berta, 2015) under the title Increasing OCB: the influence of commitment and organizational support and justice found that in the interests of increasing the behavior of OCB extra-role workplaces related to work attitudes and work motivation, one of which arose from the feeling of support from the organization to employees that shows the influence of organizational justice so that it increases affective commitment to the formation of behavioral intentions on employees. Organizational support that gives a positive influence on increasing commitment to the organization also gives employees a positive influence on extra role behavior in the work environment. The perception variables of organizational support have a positive and significant influence on organizational commitment

\section{Effects of Transformational Leadership on Organizational Citizenship Behavior.}

Each leader basically has a different style of leadership called leadership style. The leadership style carried out by a leader in influencing the behavior of others can be influenced by the nature of the leader himself. The leadership style is one that can influence the behavior of organizational citizenship behavior of employees so that it has a positive impact on the organization. Examples of improving service quality and improving group performance. Behavior of organizational citizenship behavior employees will influence employee commitment in improving efficiency, effectiveness, and creativity in the organization through its contribution to resource transformation, innovation and adaptability.

Leaders can establish mechanisms to maintain, develop and change OCB behavior of employees. The OCB mechanism taught by leaders is then adapted by their followers through the process of socialization. The process of socialization in an effort to send this vision and mission requires 
appropriate leadership, so that it can improve the behavior of a strong organizational citizenship. Transformational leaders have a big influence and can inspire followers (followers) to exclude personal interests for the good of the organization. Transformational leaders pay great attention to their followers 'self-development needs, changing followers' awareness of the issues that exist within the organization and giving views on existing problems in new ways. In a study entitled Transformational leadership and performance outcomes: Analyzes of multiple mediation pathways, the results of a significant influence between transformational leadership on increasing organizational commitment have resulted. Transformational leadership influences job satisfaction and commitment affective organizations mediate the relationship between transformational leadership and task performance (task performance) of employees, so that employees become more willing to engage with OCB behavior ( $\mathrm{Ng}$, 2017).

\section{The Effect of Perceived Organizational Support on Organizational Citizenship Behavior.}

Perceived Organizational Support emphasizes the existence of social exchange relationships between employees and organizations. This illustrates the general perception of employees regarding the extent to which organizations can appreciate the contributions they have made and how organizations care about their lives. In other words it can be concluded if there is a large organizational commitment to employees can foster voluntary behavior for employees in carrying out work. One understanding of social exchange theory is that if individuals are treated well by others, they will feel obliged to reciprocate with good treatment (Fung et al., 2012). In a study entitled "The impact of perceived organizational support and psychological empowerment on job performance: The mediating effects of organizational citizenship behavior" resulted in the conclusion that POS positively influenced $O C B$, ie perceived organizational support at a high level would create an obligation for individuals to provide reciprocity. This reciprocity can be in the form of increasing OCB behavior of hotel employees as a research sample (Chiang \& Hsieh, 2012). 5. Effect of Transformational Leadership, on Organizational Citizenship Behavior that is mediated by Organizational Commitment. Transformational leadership can determine work commitment through employee direction, provide motivation and inspiration to foster teamwork, self-actualization and achievement of goals. Organizational commitment provides an important role in mediating from transformational leadership to OCB. Organizational commitment addresses the motives associated with OCB behavior and can be the driving factors that influence the increase in OCB behavior. Research from Thomas $\mathrm{Ng}(\mathrm{Ng}, 2017)$ in his research entitled Transformational leadership and performance outcomes: Analyzes of multiple ediation pathways, a study of 416 samples using structural equation modeling (SEM) found that transformational leadership had a positive influence on OCB behavior with commitment affective as mediator. Affective commitment is an indicator of organizational commitment.

\section{Result and Discussion}

After a study of the quality of the study, data extraction is then carried out. Data extraction is done by analyzing data based on years of publication, journal, and country

Table 1 Articles distribution by Year

\begin{tabular}{lcc}
\hline No & Publication Years & Number of Articles \\
\hline 1 & 2013 & 7 \\
\hline 2 & 2014 & 4 \\
\hline 3 & 2015 & 3 \\
\hline 4 & 2016 & 5 \\
\hline 5 & 2017 & 3 \\
\hline 6 & 2018 & 4 \\
\hline 7 & 2019 & 1 \\
\hline & Total & 27 \\
\hline
\end{tabular}


As shown in the Table, the number of review studies has grown rapidly since 2013 and is likely to continue increasing in the next five-year interval. The publication trend of review studies evidences the increasing importance of review type studies in employee performance research and reflects the maturity of the discipline

Table 2 Article distribution between 2013-2019

No Journal

\begin{tabular}{|c|}
\hline $\begin{array}{c}\text { Number of } \\
\text { Articles }\end{array}$ \\
\hline 1 \\
\hline 1 \\
\hline 1 \\
\hline 1 \\
\hline 1 \\
\hline 1 \\
\hline 1 \\
\hline 1 \\
\hline 1 \\
\hline 1 \\
\hline 1 \\
\hline 1 \\
\hline 1 \\
\hline 1 \\
\hline 1 \\
\hline 1 \\
\hline 1 \\
\hline 1 \\
\hline 1 \\
\hline 1 \\
\hline 1 \\
\hline 1 \\
\hline 1 \\
\hline 1 \\
\hline 1 \\
\hline 1 \\
\hline
\end{tabular}

Global Journal of Human Resource Management,

Academy of Strategic Management Journal,

Hospitality Review,

Management of Science.

International Journal of Research in Business Management,

Eurasian Journal of Business and Economics,

European Journal of Management and Business Economics,

International Journal of Learning and Development,

International Journal of Business and Management.

International Journal of Human Resource Management.

International Journal of Advances in Management and Economics,

Journal of Intellectual Capital.

International Journal of Business and Social Science.

International Journal of Advanced Research,

Centria University Of Applied Sciences.

Journal of Vocational Behavior

International Journal of Business and Social Science,

Journal of Economics, Business \& Accountancy Ventura

International Scientific Research Journal.

Kelaniya Journal of Human Resource Management

European Journal of Human Resource Management Studies

Journal of Business and Management.

European Jurnal of Business and Management

Issues in Business Management and Economics,

Evidence-Based HRM

Journal of Planning Education and Research.

Table 3. Articles distribution by Country

\begin{tabular}{clc}
\hline No & Country & $\begin{array}{c}\text { Number of } \\
\text { Articles }\end{array}$ \\
\hline 1 & Hungaria & 3 \\
\hline 2 & Indonesia & 2 \\
\hline 3 & Mexico & 1 \\
\hline 4 & Thailand & 2 \\
\hline 5 & Vietnam & 3 \\
\hline 6 & Japan & 2 \\
\hline 7 & Bangladesh & 2 \\
\hline 8 & Malaysia & 2 \\
\hline & Total & 27 \\
\hline
\end{tabular}


Table 3 shows the number of publications by country in ten-year intervals from 2013 to 2019. Overall, 3 review studies were published from Kenya Country, and 4 review studies were published from IndonesiaCountry, review studies were published from India Country, and review studies were published from Vietnam Country.

\section{Conclusion}

Based on the results of the review literature, it can be conclude that Effect of Transformational Leadership, PEP and POS on OCB. The results of this review are only a conceptual starting point for starting an integrated discipline. It is realized that this literature study has several shortcomings, including the minimum number of publication provider websites that are used as data sources. In addition to the three websites that are used as data sources in this literature review, there are actually many more websites that provide scientific publications. However, the website cannot be included because of the limited access that the author has. Thus further studies need to be improved on the wider literature sources to gain an understanding of the implementation of concepts in more diverse case studies

\section{References}

Ahdiyana, Marita. (2010). Dimensi Organizational Citizenship Behavior (OCB) dalam Kinerja Organisasi. Journal of Applied Psychology, 8(2), 1-10

Bushra, Fatima. Ahmad Usman and Asvir Naveed. (2011). Effect of Transformational Leadership on Employees' Job Satisfaction and Organizational Commitment in Banking Sector of Lahore (Pakistan).International Journal of Business and Social Science. Vol. 2 . No. 18. pp. 261-267.

Chiang, C.-F., \& Hsieh, T.-S. (2012). The impacts of perceived organizational support and psychological empowerment on job performance: The mediating effects of organizational citizenship behavior. International Journal of Hospitality Management.31(1), 180190.doi:10.1016/j.ijhm.2011.04.011

Chin, W. W. (1998). The partial least squares approach for structural equation modeling. In Modern methods for business research. https://doi.org/10.1016/j.aap.(2008).12.010

Garg, S., \& Dhar, R. L. (2014). Effects of stress, LMX and perceived organizational support on service quality: Mediating effects of organizational commitment. Journal of Hospitality and Tourism Management, 21, 64-75.doi:10.1016/j.jhtm.2014.07.002

Han, S. H., Seo, G., Yoon, S. W., \& Yoon, D.-Y. (2016). Transformational leadership and knowledge sharing. Journal of Workplace Learning, 28(3), 130-149. doi:10.1108/jwl-09-2015-0066

Hemsworth D., Muterera J., Baregheh A. (2013). Examining Bass's Transformational Leadership In Public Sector Executives: A Psychometric Properties Review. The Journal of Applied Business Research, Volume 29, Number 3. DOI: 10.19030/jabr.v29i3.7785.

Hendrawan, Andi. Sucahyawati, Hari. Indriyani. (2017). Organizational Citizenship Behavior (OCB) pada karyawan Akademi Maritim Nusantara. Jurnal Unimus. 2252.

Huang, C.C., You, C.S., And Tsai, M.T. (2012). A Multidimensional Analysis of ethical Climate, Job Satisfaction, Organizational Commitment, and Organizational Citizenship Behavior, Nursing Ethics, Vol 19, No.4 pp. 513-529.

Hughes, R.L., Ginnett, R.C., and Curphy, G.J. (2012). Leadership: Memperkaya Pelajaran dari Pengalaman, Edisi Ketujuh, Jakarta: Salemba Humanika

Indarti, S., Solimun, Fernandes, A. A. R., \& Hakim, W. (2017). The effect of OCB in relationship between personality, organizational commitment and job satisfaction on performance. Journal of Management Development,36(10),1283-1293. doi:10.1108/jmd-11-2016-0250

Kang, D., Stewart, J., \& Kim, H. (2011). The effects of perceived external prestige, ethical organizational climate, and leader-member exchange (LMX) quality on employees' commitments and their subsequent attitudes. PersonnelReview,40(6),761-784.doi:10.1108/00483481111169670 
Keskes, I., Sallan, J. M., Simo, P., \& Fernandez, V. (2018). Transformational leadership and organizational commitment. Journal of Management Development, 37(3), 271284. doi:10.1108/jmd-04-2017-0132

Kumar, K., Bakhshi, A., and Rani, E. (2009). Linking theBig Fiv e Personality Domains to Organizational C itizenship Behavior. International Journal of Psychological Studies, Vol $1 \mathrm{~N}$ o 2, pp. 73-81.

Lin, RS. And Hsiao, J. (2014) "The relationship between transformasional leadership, knowledge sharing, trust and organizational citizenship behavior". International Journal of innovation, management and technology. Vol.5 No.3,pp. 171-174.

Ng, T. W. H. (2017). Transformational leadership and performance outcomes: Analyses of multiple mediation pathways. The Leadership Quarterly, 28(3), 385-417. doi:10.1016/j.leaqua.2016.11.008

Pekdemir, I. M., \& Turan, A. (2014). The Mediating Role of Organizational Identity Complexity Congruence on the Relationship between Perceived Organizational Prestige and In-Role ExtraRole Performance. International Journal of Business and Social Science, 5(9), 119- 131.

Perreira, T., \& Berta, W. (2015). Increasing OCB: the influence of commitment, organizational support and justice. Strategic HR Review, 14(1/2), 13-21. doi:10.1108/shr-01-2015-0003

Podnar, K. (2011). Perceived External Prestige, Organizational indentification and Organizayional Commitment: An Empirical Examination. TEORIJA IN PRAKSA let. 48, 6/2011

Robbins, Stephen P. dan Judge, Timothy A. (2008). Perilaku Organisasi. Edisi kedua belas, Salemba Empat, Jakarta.

Sušanj, T., Znidar, K., \& Pavicic, J. (2017). The Key Determinants of Perceived External PRESTIGE ( PEP ) - Qualitative Research Approach Preliminary communication. Management, 22(1), 49-8.

Titisari, P.(2014).Peranan Organizational Citizenship Behavior (OCB) dalam Meningkatkan Kinerja Karyawan. Jember : Mitra Wacana Media.

Tuna, M., Ghazzawi, I., Yesiltas, M., Tuna, A. A., \& Arslan, S. (2016). The effects of the perceived external prestige of the organization on employee deviant workplace behavior: The mediating role of job satisfaction. International Journal of Contemporary Hospitality Management (Vol. 28). https://doi.org/10.1108/IJCHM-04-2014-0182

Welty Peachey, J., J. Burton, L., \& E. Wells, J. (2014). Examining the influence of transformational leadership, organizational commitment, job embeddedness, and job search behaviors on turnover intentions in intercollegiate athletics. Leadership \& Organization Development Journal, 35(8), 740-755. doi:10.1108/lodj-10-2012-0128

Welty Peachey, J., J. Burton, L., \& E. Wells, J. (2014). Examining the influence of transformational leadership, organizational commitment, job embeddedness, and job search behaviors on turnover intentions in intercollegiate athletics. Leadership \& Organization Development Journal, 35(8), 740-755. doi:10.1108/lodj-10-2012-0128

Willy, Abdillah dan Jogiyantoi, (2015). Partial Least Square (PLS): Alternatif Structural Equation Modelling (SEM) dalam Penelitian Bisnis. Yogyakarta: ANDI.

Yoon, D., Jang, J., \& Lee, J. (Jay). (2016). Environmental management strategy and organizational citizenship behaviors in the hotel industry. International Journal of Contemporary Hospitality Management, 28 (8),1577-1597.doi:10.1108/ijchm-10-2014-0498

Yukl, Gary. (2010). Leadership In Organizations, Seventh Edition, New Jersey: Pearson Education, Inc. 